\title{
Organic amendment, biocontrol agents and soil solarization practice in management of Fusarium wilt of carnation caused by Fusarium oxysporum Schledit. f.sp. dianthi (Prill. and Del.) Snyd. and Hans.
}

\section{SUNITA CHANDEL}

Department of Plant Pathology, Dr. Y.S.P University of Horticulture and Forestry, Nauni, SOLAN (H.P.) INDIA

\section{ARITCLE INFO}

Received : 30.01 .2015

Revised : 19.02 .2015

Accepted : 07.03.2015

KEY WORDS :

Carnation, Wilt, Organic amendment, Soli solarization

*Corresponding author:

Email: schandelmpp@ rediffmail.com

\begin{abstract}
Carnation is severely affected by Fusarium oxysporum f.sp. dianthi which considerably affect the yield and quality of the flowers. Use of organic amendments, biological control agents and soil solarization alone and in combination with antagonists was tried in the present investigation. The results revealed that neem cake and pine needles out of nine organic amendments gave 77.49 and 72.49 per cent disease control with minimum disease incidence. Combined application of two antagonists Trichoderma viride and T.harzianum after 60 days of soil solarization practices registered minimum incidence (16.25\%) of the disease followed by $T$. viride and T. harzianum. The growth characteristics stem length, number of flowers and flower size per plant also increased significantly in these treatments.
\end{abstract}

How to view point the article : Chandel, Sunita (2015). Organic amendment, biocontrol agents and soil solarization practice in management of Fusarium wilt of carnation caused by Fusarium oxysporum Schledit. f.sp. dianthi (Prill. and Del.) Snyd. and Hans. Internat. J. Plant Protec., 8(1) : $130-133$.

HIND AGRICULTURAL RESEARCH AND TRAINING INSTITUTE 